\title{
Preliminary Anti-bacterial Activity of Some Indigenous Plants of Bangladesh
}

\author{
Hasina Yasmin ${ }^{1}$, Md. Abul Kaisar², Md. Moklesur Rahman Sarker ${ }^{3}$, \\ Mohammed Shafikur Rahman ${ }^{4}$ and Mohammad A. Rashid ${ }^{2}$ \\ ${ }^{1}$ Department of Pharmacy, State University of Bangladesh, Dhaka-1205, Bangladesh \\ ${ }^{2}$ Department of Pharmaceutical Chemistry, University of Dhaka, Dhaka-1000, Bangladesh \\ ${ }^{3}$ Department of Immunochemistry, Division of Pharmaceutical Sciences, Okayama University Graduate School \\ of Medicine, Dentistry and Pharmaceutical Sciences, Tsushima-naka, Okayama, 700-8530, Japan \\ ${ }^{4}$ Department of Production and Product Development, NOVO Healthcare and Pharma Ltd., Mirpur, \\ Dhaka-1207, Bangladesh
}

\begin{abstract}
The antibacterial activity of petroleum ether, carbon tetrachloride and chloroform soluble fractions of crude methanol extracts of nine indigenous plant species of Bangladesh was evaluated by the agar diffusion method. Kanamycin (30 $\mu \mathrm{g} / \mathrm{disc}$ ) was used as a standard antibacterial agent. The results indicated that all the nine plant species (not all partitionates) exhibited moderate to potent antibacterial activity against a wide variety of gram- positive and gram-negative bacteria at a concentration of $400 \mu \mathrm{g} / \mathrm{disc}$. Among them the carbon tetrachloride soluble fraction of whole plant extract of Corriandrum sativum (family-Apiaceae) revealed the highest antibacterial activity against Shigella boydii with zone of inhibition of $29 \mathrm{~mm}$.
\end{abstract}

Key words: Antibacterial activity, Disc diffusion method, Extract, Indigenous plants of Bangladesh.

\section{INTRODUCTION}

For centuries, a significant percentage of the population in Bangladesh, as elsewhere in many other developing countries, have relied on a system of traditional medicines, which consist of either empirico-rational and magico-religious elements or at times a combination of both. Infectious diseases, which account for the significant proportion of the health problems, are most often catered for by this system of medicine. Whether the approach employed is empirico-rational or magico-religious, plants constitute the center-piece of therapy in this system of medicine for restoring or maintaining well-being of the people. ${ }^{1}$

Correspondence to:

Mohammad A. Rashid

Tel.:880-2-8612069, Fax: 880-2-8612069

E-mail: rashidma@univdhaka.edu, rashid_phdu@yahoo.com

Dhaka Univ. J. Pharm. Sci. 8(1): 61-65, 2009 (June)
The discovery of modern drugs such as quinine, vincristine, digoxin, emetine, artemisine, taxol etc., from medicinal plants signify the huge potential that still exists for the production of many more novel pharmaceuticals. $^{2}$ Thus, there has recently been a resurgence of interest in the development of drugs from plants, especially from those of the developing countries that have a rich heritage of botanical ethnopharmacopoeia.

In the recent years, the development of resistance of pathogens against antibiotics has become a difficult issue caused by the indiscriminate use of modern antibiotics. ${ }^{3-9}$ So, it is important to find out newer, safer and more effective natural or synthetic antibacterial drug molecules. Considering the high cost of the synthetic drugs and their side effects, wide varieties of natural plants can be considered as a vital source for anti-microbial agents. ${ }^{1}$ Therefore, the demand for new and effective anti-microbial agents 
with broad-spectrum of activity from natural sources is increasing day by day. ${ }^{10}$ Hence, the purpose of our present investigation was to evaluate the antibacterial activity of some Bangladeshi indigenous plants for the discovery of potential antibacterial agents that might be used for the management of bacterial infectious diseases. The folkloric activity and preliminary reports of pharmacological screening of the selected plants are summarized in Table 1.

Table 1. Folkloric activity and report of pharmacological activities of the plants.

\begin{tabular}{|c|c|c|c|}
\hline $\begin{array}{l}\text { Sl } \\
\text { No. }\end{array}$ & Plant name (Family) & Folkloric uses & $\begin{array}{l}\text { Reported pharmacological } \\
\text { activities }\end{array}$ \\
\hline 1 & $\begin{array}{l}\text { Basella alba } \\
\text { (Basellaceae) }\end{array}$ & $\begin{array}{l}\text { Leaves are used in constipation, poultice for sores, urticaria, } \\
\text { gonorrhoea. }{ }^{11} \text { Roots are rubefacient and also used in poultice local } \\
\text { swellings, intestinal complaints etc. }{ }^{11}\end{array}$ & $\begin{array}{l}\text { Antidote to poisons, } \\
\text { rubefacient }^{15}\end{array}$ \\
\hline 2 & $\begin{array}{l}\text { Mentha viridis } \\
\text { (Lamiaceae) }\end{array}$ & $\begin{array}{l}\text { Whole plant is used as carminative, antispasmodic, diuretic and oil is a } \\
\text { local anesthetic, relieves toothache. }{ }^{11}\end{array}$ & No data available \\
\hline 3 & $\begin{array}{l}\text { Coriandrum sativum } \\
\text { (Apiaceae) }\end{array}$ & $\begin{array}{l}\text { Various parts of the plant are used as carminative, digestive, } \\
\text { stomachic,diuretic, aphrodisiac and tonic. }\end{array}$ & $\begin{array}{l}\text { Nematicidal, } \\
\text { hypocholesterolomic }^{17}\end{array}$ \\
\hline 4 & $\begin{array}{l}\text { Lindsaea doryphora } \\
\text { (Dennstaedtiaceae) }\end{array}$ & Laxative. $^{12}$ & No data available \\
\hline 5 & $\begin{array}{l}\text { Amaranthus oleraceus } \\
\text { (Brassicaceae) }\end{array}$ & Astringent and also use in diarrhea \& dysentery. ${ }^{13}$ & No data available \\
\hline 6 & $\begin{array}{l}\text { Ipomoea aquatica } \\
\text { (Convolvulaceae) }\end{array}$ & $\begin{array}{l}\text { Leaves and stems } \\
\text { Juice in liver complaints, as emetic, purgative and antidote to arsenic } \\
\text { poisoning. }{ }^{11}\end{array}$ & Antioxidant, ${ }^{18}$ cytotoxic ${ }^{19}$ \\
\hline 7 & $\begin{array}{l}\text { Chenopodium album } \\
\text { (Chenopodiaceae) }\end{array}$ & $\begin{array}{l}\text { Leaves are used in the treatment of hepatic disorders, spleenic } \\
\text { enlargement, dysentery } \& \text { also used as laxative and anthelmintic. }{ }^{11}\end{array}$ & Spermicidal $^{20}$ \\
\hline 8 & $\begin{array}{l}\text { Brassica juncea } \\
\text { (Fabaceae) }\end{array}$ & $\begin{array}{l}\text { Seeds are emetic, rubfacient, counter-irritant and vesicant. Leaves are } \\
\text { digestive and stomachic. }{ }^{11}\end{array}$ & Anticarcinogenic ${ }^{21}$ \\
\hline 9 & $\begin{array}{l}\text { Trigonella foenum- } \\
\text { graecum } \\
\text { (Amaranthaceae) }\end{array}$ & $\begin{array}{l}\text { Seed are demulcent, tonic, carminative, astringent, emollient etc \& } \\
\text { also used in menstrual disorders, hypertension etc. }{ }^{11}\end{array}$ & Diuretic $^{22}$ \\
\hline
\end{tabular}

\section{MATERIALS AND METHODS}

Collection and preparation of plant materials. The plants Basella alba Linn., Mentha viridis Linn., Coriandrum sativum Linn., Lindsaea doryphora Kramer, Amaranthus oleraceus Linn., Ipomoea aquatica Forsk., Chenopodium album Linn., Brassica juncea Linn. and Trigonella foenum-graecum Linn. were collected from Savar, Dhaka, Bangladesh in January 2008 and then identified at the Bangladesh National Herbarium, Dhaka, Bangladesh. The whole plant parts of the plants were cut into small pieces and dried in the sun for 10 days. The plant materials were then oven dried for 24 hours at $40^{\circ} \mathrm{C}$ to facilitate grinding into coarse powder with the help of a grinding machine.

Extraction of plant materials. $500 \mathrm{~g}$ of the coarse powder from each plant was extracted with 1.5 liter of methanol for 7 days at room temperature with occasional shaking. The extracts were then filtered off through a cotton plug and then with Whatman No. 1 filter paper and the solvent were removed with a rotary evaporator at low temperature and reduced pressure. The crude methanolic extracts were then fractionated by the modified Kupchan partition protocol $^{23}$ into petroleum ether, carbon tetrachloride and chloroform soluble materials.

Test organisms. Nine bacteria (5 gram positive and 5 gram negative, listed in Table 2) used for the experiment were collected from the stock cultures of the Institute of Nutrition and Food Sciences (INFS.), University of Dhaka, Bangladesh.

Antibacterial assay. The disc diffusion method ${ }^{24}$ was used for determination of antibacterial activity of all the fractions of extracts against ten bacteria. Dried and sterilized filter paper discs (6 mm diameter) were impregnated with known amount of 


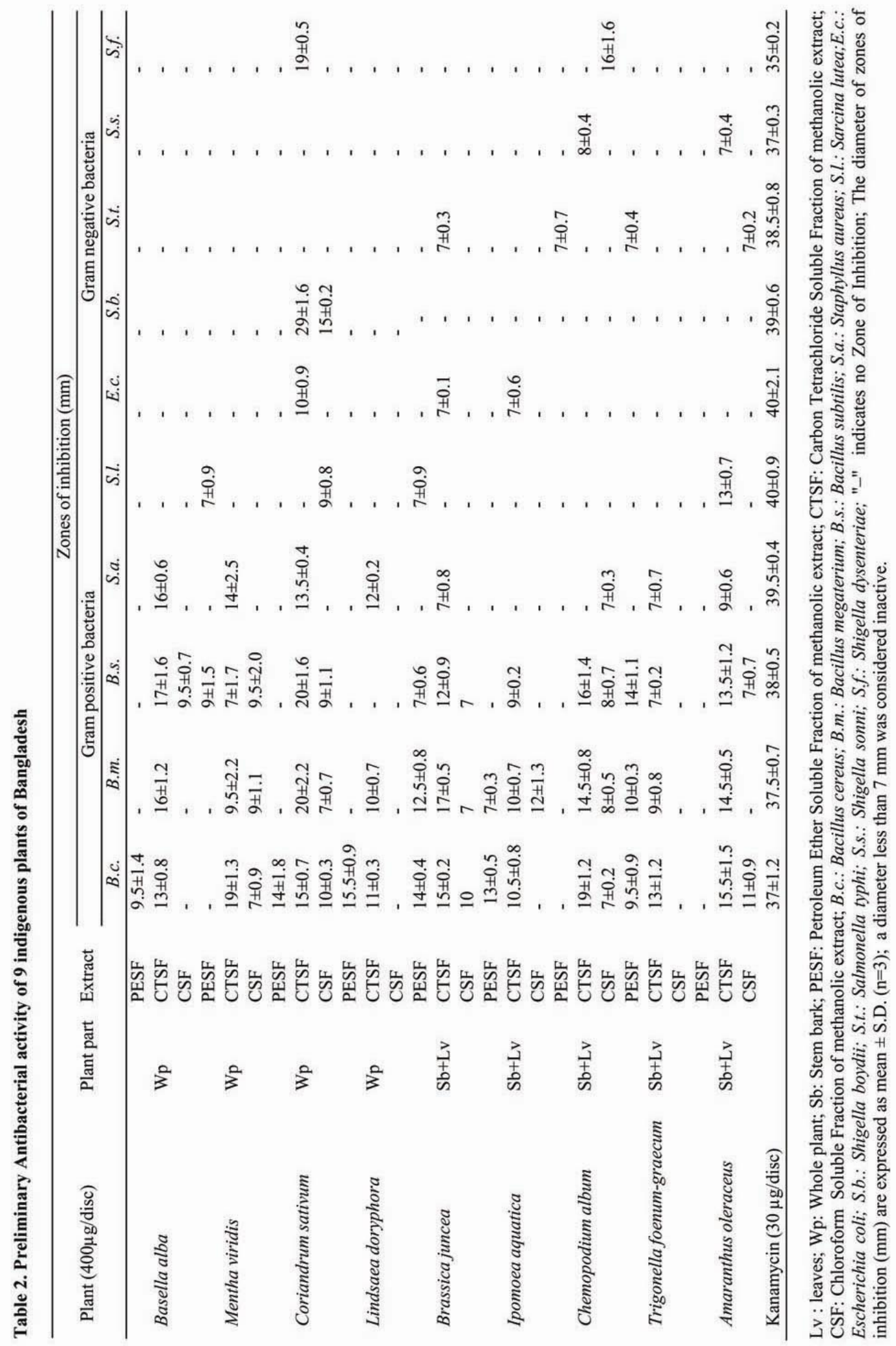


the test substances (extracts) dissolved in chloroform (400 $\mu \mathrm{g} / \mathrm{disc}$ ) using micropipette(s) and the residual solvents were completely evaporated. Discs containing the test materials (400 $\mu \mathrm{g} / \mathrm{disc}$ ) were placed on nutrient agar medium uniformly seeded with the test bacteria. Standard disc of kanamycin (30 $\mu \mathrm{g} / \mathrm{disc}$ ) and blank discs (impregnated with solvents followed by evaporation) were used as positive and negative control, respectively. These plates were then kept at low temperature $\left(4^{\circ} \mathrm{C}\right)$ for 24 hours to allow maximum diffusion of test samples and then incubated at $37^{\circ} \mathrm{C}$ for 24 hours to allow maximum growth of the microorganisms. The test materials having antibacterial activity inhibited the growth of the bacteria and a clear, distinct zone of inhibition was visualized surrounding the disc. The antibacterial activity of the test agents was determined by measuring the diameter of zone of inhibition in millimeter. The experiment was carried out in triplicate and the average zone of inhibition was calculated.

Statistical analysis. In case of each extract, three samples were prepared for the bioassay. The zones of inhibition were calculated as mean \pm S.D. $(n=3)$.

\section{RESULTS AND DISCUSSION}

The result of the investigation for the antibacterial activity of nine indigenous plants of Bangladesh has been summerized in Table 2. The findings demonstrated promising broad-spectrum antibacterial activity of carbon tetrachloride soluble fractions of methanolic extracts of $C$. sativum, $B$. juncea and $C$. album. The carbon tetrachloride soluble fraction of $B$. alba showed mild to moderate antibacterial activity against Bacillus cereus (13 $\mathrm{mm})$, B. megaterium $(16 \mathrm{~mm})$, B. subtilis $(17 \mathrm{~mm})$ and Staphylococcus aureus (16 mm), whereas the carbon tetrachloride soluble partitionate of $M$. viridis demonstrated potent antibacterial activity against $B$. cereus. In case of carbon tetrachloride soluble fraction of methanolic extract of $C$. sativum, the result revealed that it exhibited potent antibacterial activity against $B$. megaterium $(20 \mathrm{~mm}), B$. subtilis (20 mm), Shigella boydii (29 $\mathrm{mm})$ and S. dysenteriae
(19 mm), whereas its chloroform soluble fraction exhibited moderate antibacterial activity against $S$. boydii $(15 \mathrm{~mm})$. The wide and strong antibacterial activity of $C$. sativum dictates its potential as a source of active chemicals that might be used for the discovery of new antibacterial agent. On the other hand, the carbon tetrachloride soluble fraction of methanolic extract of $B$. juncea also showed mild to moderate antibacterial activity against $B$. cereus (15 $\mathrm{mm})$, B. megaterium $(17 \mathrm{~mm})$ and $B$. subtilis $(12$ $\mathrm{mm})$. C. album by its carbon tetrachloride soluble fraction inhibited the growth of $B$. cereus, $B$. megaterium and $B$. subtilis with the average zone of inhibition of $19 \mathrm{~mm}, 14.5 \mathrm{~mm}$ and $16 \mathrm{~mm}$ respectively, whereas its chloroform soluble materials inhibited the growth of $S$. dysenteriae with the zone of inhibition $16 \mathrm{~mm}$. The carbon tetrachloride soluble extract of $A$. oleraceus showed mild to moderate antibacterial activity against $B$. cereus $(15.5 \mathrm{~mm})$, B. megaterium $(14.5 \mathrm{~mm}), B$. subtilis $(13.5 \mathrm{~mm})$ and $S$. lutea $(13 \mathrm{~mm})$.

The results obtained from the preliminary evaluation of antibacterial activity of nine plants in the experiment is an evidence that a number of Bangladeshi indigenous plants can be a vital source of promising antibacterial agents and thus can be considered as leads for the discovery of new antibacterial drugs. Further investigation is also needed for proper utilization of these plants as antibacterial agents either in traditional medicines directly or as sources for active antibacterial principle(s).

\section{ACKNOWLEDGEMENT}

The authors would like to express their gratefulness to the Institute of Nutrition and Food Sciences, University of Dhaka, Bangladesh for supplying the test organisms to conduct this research work. 


\section{REFERENCES}

1. Geyid, A., Abebe, D., Debella, A., Makonnen, Z., Aberra, F., Teka, F., Kebede, T., Urga, K., Yersaw, K., Biza, T., Mariam, B.H. and Guta, M. 2005. Screening of some medicinal plants of Ethiopia for their anti-microbial properties and chemical profiles. J. Ethnopharmacol 97, 421422.

2. Plokin, N.J. 1988. Conservation, ethnobotany and the search for jungle medicine: pharmacology comes of age ... again. Pharmacotherapy 8, 257-262.

3. Kunin, C.M. 1993. Resistance to Antimicrobial Drugs - A Worldwide calamity. Ann. Intern. Med. 118, 557-561.

4. Kunin, C.M. 1983. Antibiotic resistance - a world health problem we cannot ignore (Editorial). Ann. Intern. Med. 99, 859-860.

5. Control of antibiotic-resistant bacteria: memorandum from a WHO meeting. Bull. World Health Organ. 1983, 61, 423433.

6. Burke, J.P. and Levy, S.B. 1985. Summery report of worldwide antibiotic resistance: international task forces on antibiotic use. Rev. Infect. Dis. 7, 560-564.

7. Kunin, C.M., Lipton, H.L., Tupasi, T., Sacks, T., Scheckler, W.E., and Jivani, A. 1987. Social, behavioral and practical factors affecting antibiotic use worldwide: report of Task Force 4. Rev. Infect. Dis. 9, 270-285.

8. Cohen, M.L. 1992. Epidemiology of drug resistance: implications for a post-antibacterial era. Science 257, 10501055.

9. Neu, H.C. 1992. The crisis in antibiotic resistance. Science 257, 1064-1073.

10. Rahman, M.S., Rahman, M.Z., Wahab, M.A., Chowdhury, R. and Rashid, M.A. 2008. Antimicrobial Activity of Some Indigenous Plants of Bangladesh. Dhaka Univ. J. Pharm. Sci. 7, 23-26.

11. Ghani, A. 1998. Medicinal Plants of Bangladesh. Asiatic Society of Bangladesh, Dhaka, p-97, 104, 126, 141, 201, 230.

12. www.wikipedia.org.

13 Grieve, M. 1978. A modern herbal: The medicinal, culinary, cosmetic and economic properties, cultivation and folk-lore of herbs. Dover Publications Inc., New York. p. 427

14. Duke. J. A. and Ayensu. E. S. Medicinal Plants of China. Reference Publications, Inc. 1985ISBN0-917256-20-4.
15. Manandhar. N. P. Plants and People of Nepal Timber Press. Oregon. 2002 ISBN 0-88192-527-6.

16. Junheon Kim, Sun-Mi Seo, Sang-Gil Lee, Sang-Chul Shin and Il-Kwon Park. 2008. Nematicidal Activity of Plant Essential Oils and Components from Coriander (Coriandrum sativum), Oriental Sweetgum (Liquidambar orientalis), and Valerian (Valeriana wallichii) Essential Oils against Pine Wood Nematode (Bursaphelenchus xylophilus) J. Agric. Food Chem. 56, 7316-7320.

17. Mohamed Fawzy Ramadan, Mohamed Mostafa Afify Amer, and Ahmed El-Said Awad 2008. Coriander ( Coriandrum sativum L.) seed oil improves plasma lipid profile in rats fed a diet containing cholesterol. J. Europ. Food Res. Technol. 227, 1173-1182.

18. Prasad, S. Divakar., G. R. Shivamurthy and S. M. Aradhay. 2005a. Isolation of a free radical scavenging antioxidant from water spinach (Ipomoea aquatica Forsk) J. Sci. Food Agri. 85, 1461-1468.

19. Prasad, N. K., R. Chandrashekar, G. Ashok., G. R. Shivamurthy, P. Vijayan and S. M. Aradhay. 2005b. Cytotoxic properties of Ipomoea aquatica Forsk leaf. Ind. J. Pharmacol. 37, 397-398.

20. Kumar S., Biswas S., Mandal D., Roy H.N, Chakraborty S, Kabir SN, Banerjee S., Modal NB. 2007. Chenopodium album seed extract: a potent sperm-immobilizing agent both in vitro and in vivo. Contraception 75, 71-80.

21. Richard Mithen. 2001. Glucosinolates-biochemistry, genetics and biological activity. Plant Growth Regulation 34, 91-103.

22. R.M. Rohini, Naira Nayeem, Amit Kumar Das. 2009. Diuretic effect of Trigonella foenum-graecum seed extracts. The Inter. J. Alternat. Med. 6.

23. Van Wagenen, B. C., Larsen, R., Cardellina, J. H. II, Ran dazzo, D., Lidert., Z. C. and Swithenbank, C. 1993. Ulosantoin, a potent insecticide from the sponge Ulosa ruetzleri. J. Org. Chem. 58, 335-337.

24. Bauer, A.W., Kirby, W.M.M., Sheriss, J.C. and Truck, M. 1966. Antibiotic susceptibility testing by standardized single method. Amer. J. Clin. Path. 45, 493-496. 